Session 1166

\title{
A Cooling, Heating, and Power for Buildings (CHP-B) Instructional Module
}

\author{
B. K. Hodge, J. D. Hardy \\ Mississippi State University
}

\begin{abstract}
Cooling, Heating, and Power for Buildings (CHP-B) is an important emphasis area for the U. S. Department of Energy (USDOE). By coupling local electricity generation (fuel cells, gas turbines, internal combustion engines) with thermally-activated components (absorption chillers, desiccants, heat recovery steam generators) system thermal efficiencies in excess of 80 percent are possible. This paper describes an instructional module that succinctly discusses CHP components. The module, which is designed for use in senior-level engineering courses, contains first-order descriptions of prime movers as well as thermally-regenerated components. The module contains references, web-site addresses, manufacturers' information and web sites, pictures, a case study, example problems, and system schematics for CHP-B systems. The intent is that the CHP module is instructor ready and can be used to readily introduce CHP concepts in a variety of engineering courses. This instructional module provides engineering educators a quick, complete, but first order, way to incorporate CHP into engineering courses. Information for obtaining the module is provided.
\end{abstract}

\section{Background}

Cooling, Heating, and Power for Buildings (CHP-B) is an important twenty-first century emphasis area for the U. S. Department of Energy (USDOE). By coupling local electricity generation (gas turbines, fuel cells, internal combustion engines,...) with thermally-activated building systems (absorption chillers, desiccant dehumidifiers, heat recovery steam generators,...) system thermal efficiencies in excess of 80 percent are possible. The high thermal efficiencies of CHP-B systems contrast with the near-30 percent thermal efficiencies of standalone, simple-cycle, fossil-fuel power plants. The USDOE perspective on CHP-B is available on the web site (1) www.chpb.net. The USDOE is interested in CHP-B because the wide-spread adoption and use of CHP systems would markedly reduce fossil fuel consumption (promoting less dependence on foreign oil), would reduce green house gas emissions, and could result in better indoor environmental quality (IEQ) for residential, commercial, and industrial buildings.

Although none of the CHP-B component technologies are new and although cogeneration and combined cycle applications are well established, the goal of the CHP-B program is that CHP-B systems should become pervasive in institutional, commercial, and industrial facilities. A

Proceedings of the 2003 American Society for Engineering Education Annual Conference \& Exposition Copyright (O) 2003, American Society for Engineering Education 
paradigm shift from conventional grid-based energy to CHP-B can occur only if the architectural and engineering communities routinely consider CHP-B as a viable option. Routine consideration CHP-B requires that architects and engineers be familiar with CHP-B concepts, and one place to start building such familiarity is at the undergraduate level. However, while current textbooks contain elements of CHP-B, these textbooks do not explicitly address either the CHP-B concept or the details. What is needed is an instructor-friendly collection of CHP-B information suitable for integration into undergraduate courses using currently-available textbooks. Oak Ridge National Laboratory (ORNL) funded the Department of Mechanical Engineering at Mississippi State University (MSU) to develop an instructional CHP-B module suitable for use at the undergraduate level in a variety of courses. This paper explores the details and availability of the Cooling, Heating, and Power for Buildings (CHP-B) Instructional Module (2).

\section{Pedagogical Issues}

The basic approach followed was to organize and collate a body of CHP-B knowledge in a fashion useful to instructors at the college/university level. In 1996, the Global Center for Desiccant Technology (GCDT) at MSU developed, distributed, and updated through three editions the Desiccant Dehumidification Curriculum Module for Engineering/Technology HVAC Courses (3). However, CHP-B topics in 2002 present several differences from desiccant topics in 1996. For example, in 1996 little instructional information was readily available about desiccant systems, but in 2002 a plethora of information (in web sites and textbooks) is readily available about components used in CHP-B system. Additionally, CHP-B is a much broader topic than gas-regenerated desiccants, the internet is much more pervasive as a purveyor of information, and CHP-B is a prime emphasis area of the U. S. Department of Energy. Moreover, the target audience for CHP-B is much broader and is much more interdisciplinary than the target audience for desiccant topics. Desiccant topics are generally associated with HVAC technology, but CHP-B topics are of interest to several engineering disciplines as well as to non-engineering disciplines. However, any effort to develop curriculum material such as a supplementary instructional module must have some attributes in common. The attributes common to any instructional module are as follows:

(1) Contain sufficient material for use in one to six class days.

(2) Present a logical development/sequence of the information.

(3) Have contents of interest to students (applications and examples more than theoretical developments).

(4) Have contents of interest to the instructor (examples, physical principles, quantitative information, source contacts, and exercises).

(5) Contain sound information with references.

(6) Be presented without hype.

The CHP-B module is written at the undergraduate level and is suitable for use in a number of senior-level undergraduate or beginning graduate courses. The module provides engineering education material that an instructor can readily integrate into a course. Elements of the module can be incorporated into a number of courses in mechanical engineering curriculums. A onelecture overview would be appropriate for an introduction to mechanical engineering course; the

Proceedings of the 2003 American Society for Engineering Education Annual Conference \& Exposition Copyright C 2003, American Society for Engineering Education 
entire module could be used in an HVAC course; various topics in the module could be incorporated into thermodynamics courses; CHP-B would be especially useful in an alternate energy systems or energy conversion courses, and CHP-B topics and components could be offered as examples in fluid mechanics, heat transfer, or thermal systems design courses. Details of the contents of the CHP-B Instructional Module are examined in the next section.

\section{Module Details and Layout}

The CHP-B Instructional Module is divided into nine chapters and contains an extensive reference list. Table 1 presents the organization of the module. Much of the information included in the module is taken from web sites, manufacturers' material, and textbooks, and care has been exercised in making appropriate attributions for information included in the document. Chapters 1 and 2 are short overviews of CHP-B and are suitable for a one-day (50 minute) lecture or an introductory lecture. Chapters 3-9 contain treatments of CHP-B components. Each of the these chapters (3-9) presents, for the component covered in the chapter, topics such as an overview of fundamentals, application examples, heat recovery issues, costs, student exercises, and manufacturers' and agency contact information.

Table 1. Module Chapter Topics

\begin{tabular}{cl} 
Chapter & \multicolumn{1}{c}{ Topic } \\
1 & Introduction to CHP-B \\
2 & The CHP-B System \\
3 & Internal Combustion Engines \\
4 & Combustion Turbines \\
5 & Fuel Cells \\
6 & Heat Exchangers \\
7 & Absorption Chillers \\
8 & Desiccant Dehumidifiers \\
9 & Case Study \\
& Bibliography
\end{tabular}

Pictures, illustrations, and tables are extensively used to aid in student appeal and understanding. The Bibliography section was developed with instructors in mind and contains citations for textbooks, archival publication articles, web sites, and manufacturers' information. Some details of each chapter are presented in the following paragraphs.

Chapter 1 Introduction to CHP for Buildings

Chapter 1 establishes the overall rationale for CHP-B systems by presenting information on the relative efficiencies of conventional, combined cycle, and CHP-B systems. For example, Figure 1 is an excellent graphic that conveys both the enhanced thermal efficiency of CHP-B systems as well as some component characteristics. As with many of the figures in the module, Figure 1 was abstracted from a web site (4), www.bchp.org. 


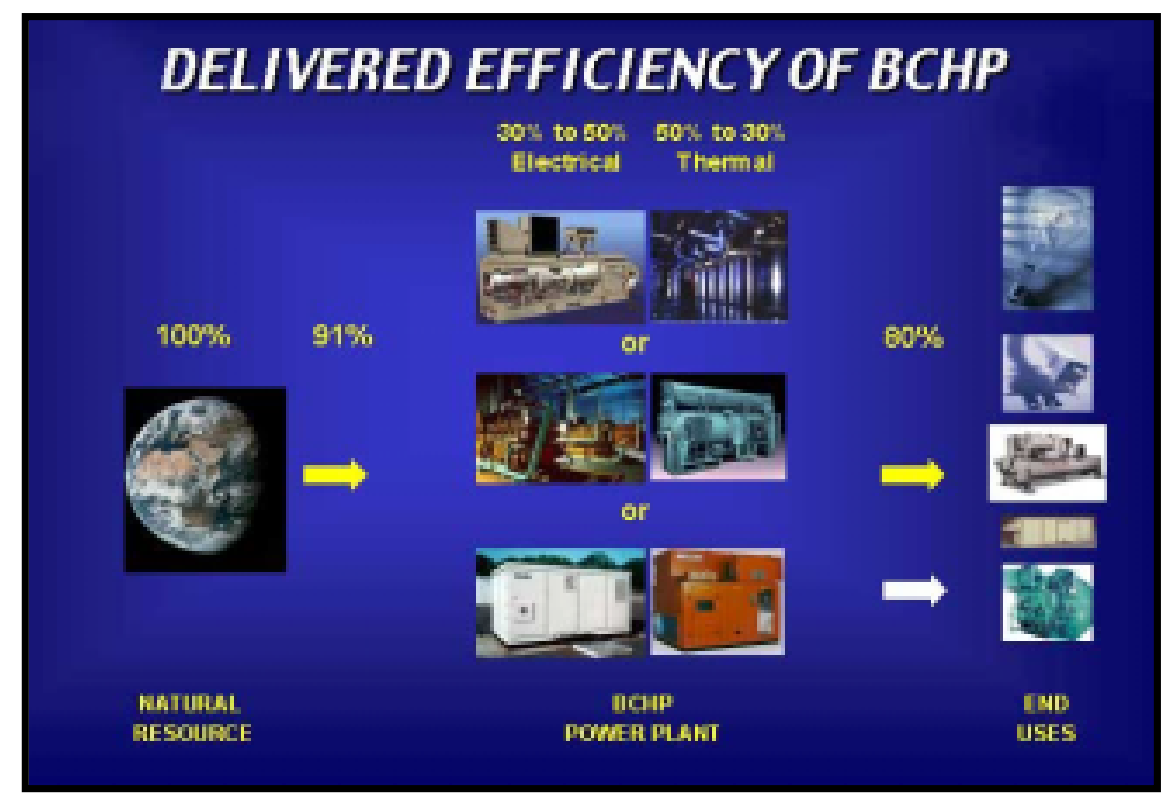

Figure 1. Efficiency of CHP-B Systems (4)

\section{Chapter 2 The CHP-B System}

Chapter 2 provides a qualitative overview of CHP prime movers (gas turbines, fuel cells, and internal combustion engines) as well as thermally-regenerated components (absorption chillers, desiccant dehumidifiers, and heat exchangers). Table 2, from

www.eren.doe.gov/der/chp/pdfs/chprev.pdf (5), is in the module, and is an excellent summary of the characteristics of the prime movers in CHP.

\section{Chapter 3 Internal Combustion Engines}

Chapter 3 Internal Combustion Engines is the first of the chapters that deal in detail with specific CHP-B system components. The chapter content is typical of the contents of Chapters 3-9 and consists of the following topics:
(1) Technology Overview
(2) Application
(3) Heat Recovery
(4) Cost
(5) IC Engines and CHP-B
(6) IC Engine Problems
(7) Manufacturers

Table 3, from www.eren.doe.gov/der/chp/pdfs/chprev.pdf (5), is abstracted from Chapter 3 and presents an overview of reciprocating engine technology. 
Table 2. Comparison of CHP Technologies (5)

\begin{tabular}{|c|c|c|c|c|c|}
\hline & Diesel Engine & $\begin{array}{l}\text { Natural Gas } \\
\text { Engine }\end{array}$ & Gas Turbine & Microturbine & Fuel Cells \\
\hline $\begin{array}{l}\text { Electric } \\
\text { Efficiency } \\
\text { (LHV) }\end{array}$ & $30-50 \%$ & $25-45 \%$ & $\begin{array}{l}25-40 \% \\
\text { (simple) } \\
40-60 \% \\
\text { (combined) }\end{array}$ & $20-30 \%$ & $40-70 \%$ \\
\hline $\begin{array}{l}\text { Power Output } \\
\text { (MW) }\end{array}$ & $0.05-5$ & $0.05-5$ & $3-200$ & $0.025-0.25$ & $0.2-2$ \\
\hline $\begin{array}{l}\text { Footprint } \\
\left(\mathrm{ft}^{2} / \mathrm{kW}\right)\end{array}$ & 0.22 & $0.22-0.31$ & $0.02-0.61$ & $0.15-1.5$ & $0.6-4$ \\
\hline $\begin{array}{l}\text { CHP installed } \\
\text { cost }(\$ / k W)\end{array}$ & $800-1,500$ & $800-1,500$ & $700-900$ & $500-1,300$ & $>3,000$ \\
\hline $\begin{array}{l}\text { O\&M } \quad \text { cost } \\
(\$ / k W)\end{array}$ & $0.005-0.010$ & $0.007-0.015$ & $0.002-0.008$ & $0.002-0.01$ & $0.003-0.015$ \\
\hline $\begin{array}{l}\text { Availability } \\
\text { (uptime) }\end{array}$ & $90-95 \%$ & $92-97 \%$ & $90-98 \%$ & $90-98 \%$ & $>95 \%$ \\
\hline $\begin{array}{l}\text { Hours between } \\
\text { Overhauls }\end{array}$ & $25,000-30,000$ & $24,000-60,000$ & $30,000-50,000$ & $5,000-40,000$ & $10,000-40,000$ \\
\hline Start-up time & $10 \mathrm{sec}$ & $10 \mathrm{sec}$ & $10 \mathrm{~min}-1 \mathrm{hr}$ & $60 \mathrm{sec}$ & 3 hrs-2 days \\
\hline $\begin{array}{l}\text { Fuel pressure } \\
\text { (psi) }\end{array}$ & $<5$ & $1-45$ & $\begin{array}{l}125-500 \\
\text { (may require } \\
\text { compressor) }\end{array}$ & $\begin{array}{l}40-100 \\
\text { (may require } \\
\text { compressor) }\end{array}$ & $0.5-45$ \\
\hline Fuels & $\begin{array}{l}\text { Diesel and } \\
\text { residual oil }\end{array}$ & $\begin{array}{l}\text { Natural gas, } \\
\text { biogas, propane }\end{array}$ & $\begin{array}{l}\text { Natural gas, } \\
\text { biogas, } \\
\text { propane, } \\
\text { distillate oil }\end{array}$ & $\begin{array}{l}\text { Natural gas, } \\
\text { biogas, } \\
\text { propane, } \\
\text { distillate oil }\end{array}$ & $\begin{array}{l}\text { Hydrogen, } \\
\text { natural gas, } \\
\text { propane }\end{array}$ \\
\hline Noise & $\begin{array}{l}\text { Moderate to } \\
\text { high (requires } \\
\text { building } \\
\text { enclosure) }\end{array}$ & $\begin{array}{l}\text { Moderate to } \\
\text { high (requires } \\
\text { building } \\
\text { enclosure) }\end{array}$ & $\begin{array}{l}\text { Moderate } \\
\text { (enclosure } \\
\text { supplied with } \\
\text { unit) }\end{array}$ & $\begin{array}{l}\text { Moderate } \\
\text { (enclosure } \\
\text { supplied with } \\
\text { unit) }\end{array}$ & $\begin{array}{l}\text { Low } \\
\text { (no enclosure } \\
\text { required) }\end{array}$ \\
\hline $\begin{array}{l}\mathrm{NO}_{\mathrm{X}} \text { emissions } \\
\text { (lb/MW-hr) }\end{array}$ & $3-33$ & $2.2-28$ & $0.3-4$ & $0.4-2.2$ & $<0.02$ \\
\hline $\begin{array}{l}\text { Uses for Heat } \\
\text { Recovery }\end{array}$ & $\begin{array}{l}\text { Hot water, LP } \\
\text { steam, district } \\
\text { heating }\end{array}$ & $\begin{array}{l}\text { Hot water, LP } \\
\text { steam, district } \\
\text { heating }\end{array}$ & $\begin{array}{l}\text { Direct heat, hot } \\
\text { water, LP-HP } \\
\text { steam, district } \\
\text { heating }\end{array}$ & $\begin{array}{l}\text { Direct heat, hot } \\
\text { water, LP steam }\end{array}$ & $\begin{array}{l}\text { Hot water, LP- } \\
\text { HP steam }\end{array}$ \\
\hline $\begin{array}{l}\text { CHP output } \\
\text { (Btu/kWh) }\end{array}$ & 3,400 & $1,000-5,000$ & $3,400-12,000$ & $4,000-15,000$ & $500-3,700$ \\
\hline $\begin{array}{l}\text { Useable Temp } \\
\text { for CHP ( } 8 \mathbf{F})\end{array}$ & $180-900$ & $300-500$ & $500-1,100$ & $400-650$ & $140-700$ \\
\hline
\end{tabular}

Table 3. Overview of Reciprocating Engine Technology (5)

\begin{tabular}{|c|c|}
\hline Commercially Available & Yes \\
\hline Size Range & $0.5 \mathrm{~kW}-6.5 \mathrm{MW}$ \\
\hline Fuel & Natural gas, diesel, landfill gas, digester gas \\
\hline Efficiency & $25-45 \%$ (primarily size dependent) \\
\hline Environmental & Emission controls required for $\mathrm{NO}_{\mathrm{x}}$ and $\mathrm{CO}$ \\
\hline
\end{tabular}

Proceedings of the 2003 American Society for Engineering Education Annual Conference \& Exposition Copyright C 2003, American Society for Engineering Education 


\section{Chapter 4 Combustion Turbines}

Of great interest in CHP-B applications are gas turbines (or combustion turbines). Chapter 4 examines both conventional turbines and the newer microturbines. Cycle analysis is reviewed and then industrial turbines and microturbines are examined from the standpoint of applications, heat recovery, cost, and CHP-B congruence. A list of manufacturers is also provided, as are exercises (problems) for students. Figure 2, taken from the module, is a schematic of a gas turbine with reheat. Table 4, taken from www.energy.ca.gov/distgen/ (6), presents a summary of microturbine characteristics.

\section{Chapter 5 Fuel Cells}

As indicated in Table 2, fuel cells possess many favorable characteristics for CHP-B use, but initial costs are a problem. Chapter 5 previews fuel cells as CHP-B prime movers. Table 5 delineates the list of topics in Chapter 5.

A fuel cell generates direct current electricity by electrochemical combination of hydrogen and oxygen. A typical fuel cell contains a fuel processor (for producing hydrogen-rich fuel), a power section (fuel cell stack), and a power-conditioning unit (to provide grid-compatible AC power). A schematic of a fuel cell as presented in the module and taken from www.dodfuelcell.com (7) is provided in Figure 3.

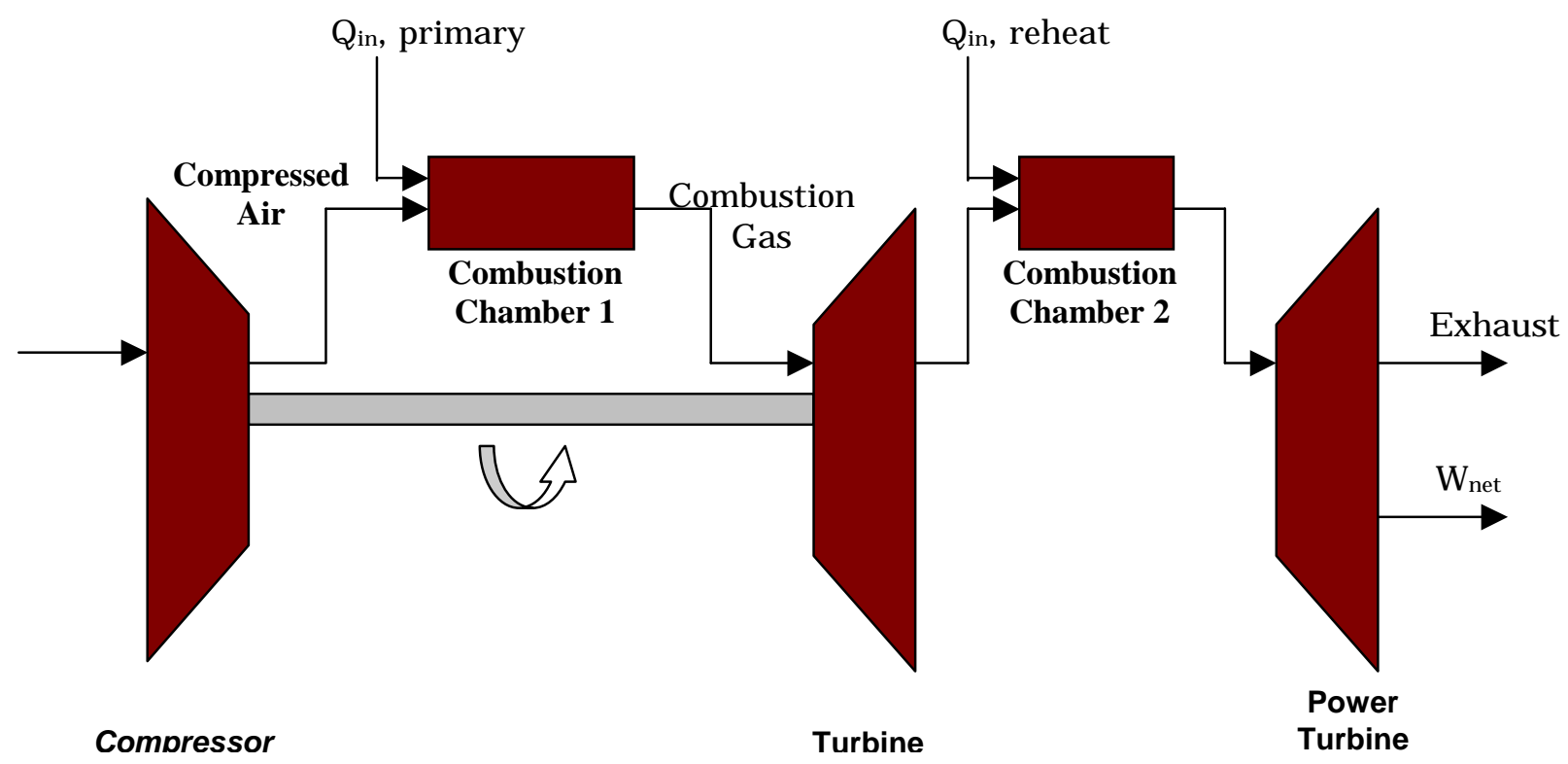

Figure 2. Gas Turbine with Reheat (2) 
Table 4. Mictoturbine Characteristics (6)

\begin{tabular}{|c|c|}
\hline \multicolumn{2}{|c|}{ Microturbine Overview } \\
\hline Commercial Status & Limited Availability \\
\hline Size Range & $25 \mathrm{~kW}-500 \mathrm{~kW}$ \\
\hline Fuel & $15 \%$ \\
\hline Unrecuperated Efficiency & $20-30 \%$ \\
\hline Recuperated Efficiency & Natural gas, hydrogen, propane, diesel \\
\hline Environmental Effects & Very low $(<9-50 \mathrm{ppm}) \mathrm{NOx}$ \\
\hline Other Features & Cogen $\left(50-80^{\circ} \mathrm{C}\right.$ water $)$ \\
\hline
\end{tabular}

Table 5. Chapter 5 Topics

Technology Overview

PAFC

MCFC

SOFC

PEMFC

Application

Heat Recovery

Fuel Cells and CHP-B

Manufacturers

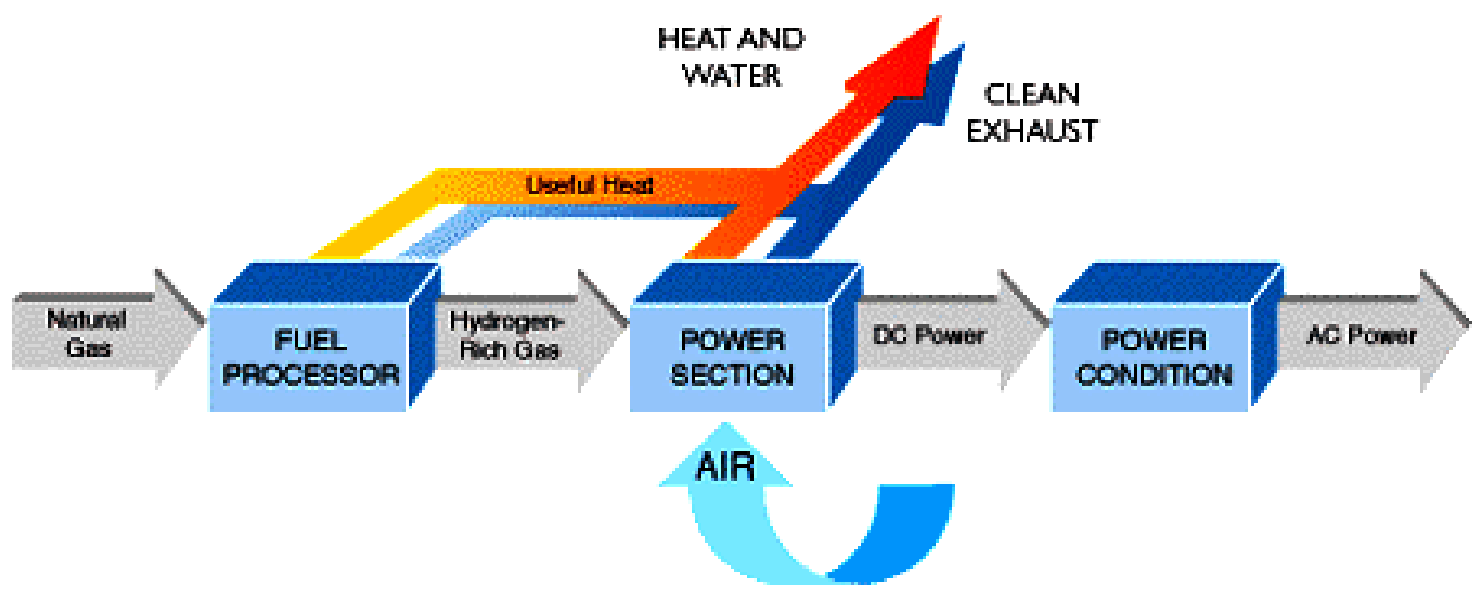

Figure 3. Fuel Cell System Schematic (7)

\section{Chapter 6 Heat Exchangers}

Because heat recovery is a necessary and critical part of CHP-B systems and because the CHP-B Instructional Module was developed for use in interdisciplinary courses as well as mechanical engineering courses, Chapter 6 covers basic heat exchanger concepts in addition to CHP-B 
applications and heat recovery steam generators. As illustrated in Figure 4, taken from Caton and Turner, 1997 (8), the concept of the pinch point is introduced and explained.

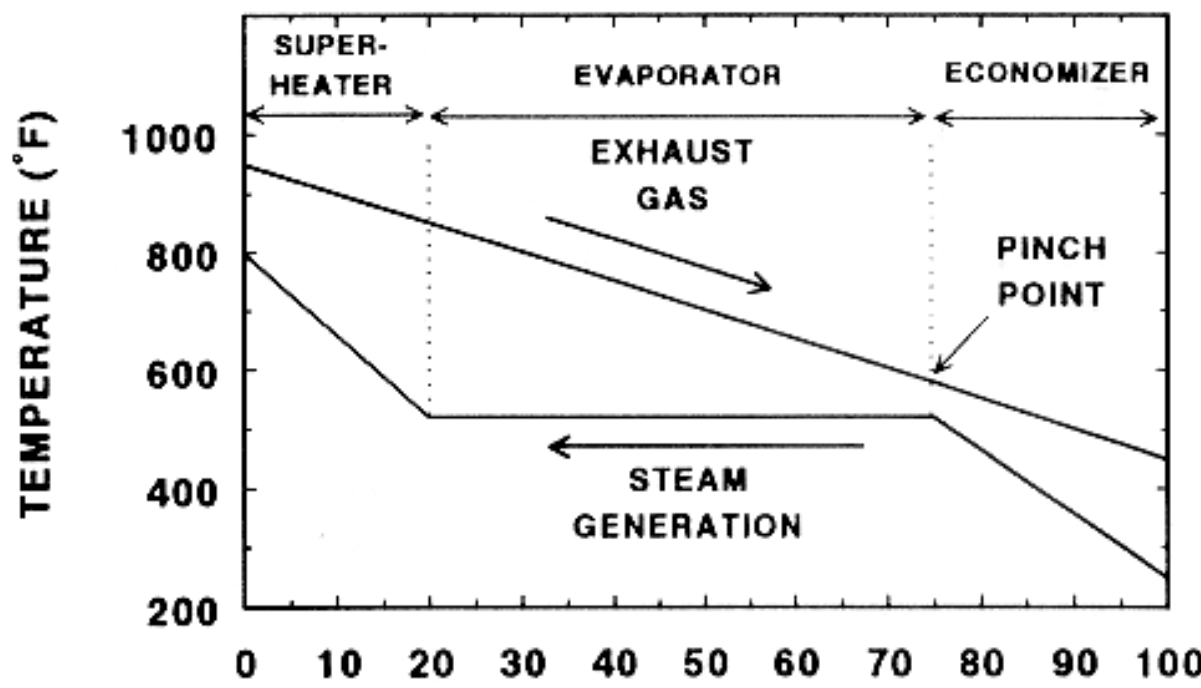

HEAT TRANSFER (\%)

Figure 4.Temperature Distributions in a Heat Recovery Steam Generator (8)

Chapter 7 Absorption Chillers

Perhaps the key component for CHP-B systems is absorption chillers-chillers that use heat to drive the cooling process. Absorption technology is heat driven, transferring heat from a low temperature to a high temperature using only heat as the driving energy. In contrast, a vaporcompression system is a work driven, not a heat driven cycle. Chapter 7 contains a technology overview including refrigerant-absorption selection, types of absorption chillers, and system analysis. As usual application, cost, absorption chillers and BCH-P, student exercises, and manufacturers' addresses and equipment are covered. Figure 5, from www.york.com (9), illustrates an absorption chiller available from York.

Chapter 8 Desiccant Dehumidifiers

Desiccant dehumidifiers are another important category of thermally-regenerated components used in CHP-B systems. Much of the contents of Chapter 8 are abstracted from the Desiccant Dehumidification Curriculum Module for Engineering/Technology HVAC Courses (3). Table 6 presents a list of topics in Chapter 8.

A schematic (3) of a desiccant dehumidification system used for re-circulated air is illustrated in Figure 6. 


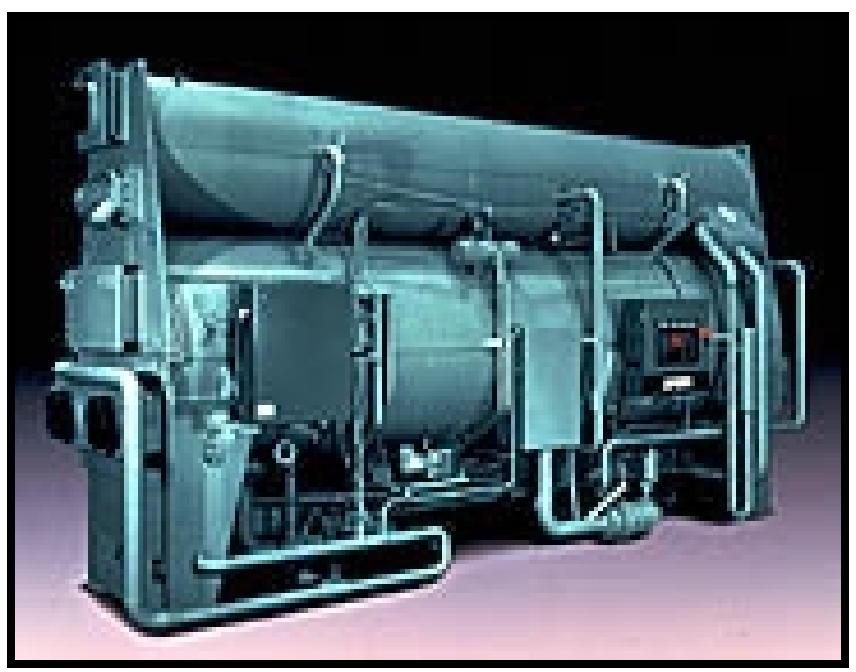

Figure 5. Single Effect Absorption Chiller (9)

Table 6. Contents of Chapter 6

Sub-cooling Systems versus Desiccant Systems

Summary of Principles of Sub-cooling Systems

Summary of Principles of Desiccant Systems

Types of Desiccant Systems

General Classification

Solid Adsorbents

Solid Absorbents

Regeneration

Solid Desiccant Systems

Cost Considerations

Manufacturers

Chapter 9 Case Study

The case study is for the Mississippi Baptist Medical Center (MBMC), a full-care 694-bed hospital located in Jackson, MS. The MBMC was chosen as a case study since the hospital has a more than 11-year history of operating a CHP-B system using a 4-MW combustion turbine, a heat recovery steam generator, and two absorption chillers. Schmidt and Hodge (10) examined the economics of the MBMC CHP-B system and concluded fuel cost savings were about $\$ 700,000 / y e a r$ in the 1994-96 time period. The MBMC online and electrical generating percentages for from 1994-2001 are summarized in Table 7 (2). 


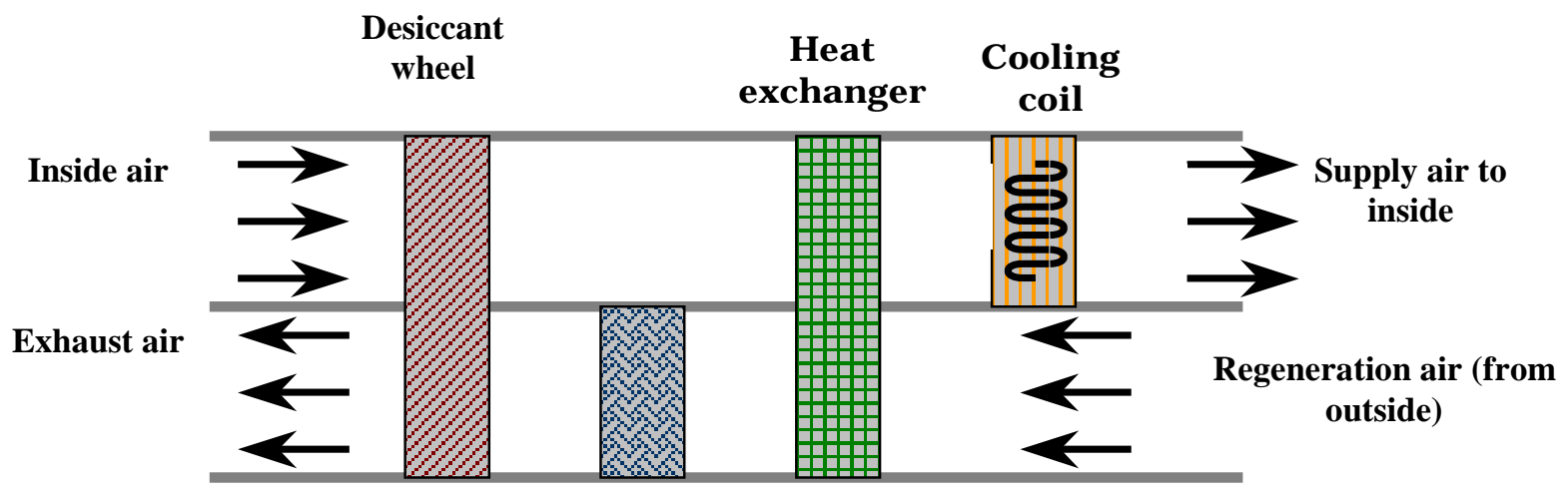

Heater

Figure 6. Re-circulated Desiccant Dehumidification System Configuration (3)

Table 7. MBMC Online and Generation Percentages (2)

\begin{tabular}{|c|c|c|}
\hline Year & Percent Generation & Online Percentage \\
\hline 1994 & 74 & 94 \\
\hline 1995 & 74 & 98 \\
\hline 1996 & 78 & 98 \\
\hline 1998 & 64 & 84 \\
\hline 1999 & 73 & 98 \\
\hline 2001 & 61 & 82 \\
\hline 2002 & 70 & 93 \\
\hline
\end{tabular}

\section{Bibliography}

Citations in the Bibliography include books, articles, agency web sites, and manufacturer web sites. Also listed are additional background information and internet resources for energy conversion topics such as cogeneration, gas turbines, and HVAC components.

\section{Module Availability}

The CHP-B Instructional Module will be available by 1 July 2003 to college-level instructors by contacting the authors at P. O. Box ME, Mississippi State, MS 39762 or at 662-325-3260 or via e-mail at hodge@me.msstate.edu. Additionally, at that time the module will be downloadable from the Mississippi State University Department of Mechanical Engineering's web site. A short registration will bes required for downloading. 


\section{Closure}

Contents of the CHP-B Instructional Module, developed at Mississippi State University, have been reviewed. Topical subjects for each chapter as well as examples of the contents of the module have been presented. Contact information for obtaining copies is also discussed.

\section{References}

1. www.chpb.net

2. Hodge, B. K., and Hardy, J. D., Cooling, Heating, and Power for Buildings (CHP-B) Instructional Module, Mechanical Engineering Department, Mississippi State University, 2003.

3.Chamra, L., Hodge, B. K., and Steele, W. G., Desiccant Dehumidification Curriculum Module for Engineering/Technology HVAC Courses, Mechanical Engineering Department, Mississippi State University, 2000, $3^{\text {rd }}$ edition.

4. www.bchp.org

5. www.eren.doe.gov/der/chp/pdfs/chprev.pdf

6. www.energy.ca.gov/distgen/

7. Www.dodfuelcell.com

8. Caton, J. A., and Turner, W. D., “Cogeneration,” CRC Handbook of Energy Efficiency, CRC Press, New York, 1997.

9. www.york.com

10. Schmidt, D., and Hodge, B. K., "Cogeneration at the Mississippi Baptist Medical Center," Engineered Systems, Vol. 15, No. 7, pp. 74-78, 1998.

B. K. Hodge: B. K. Hodge serves as the TVA Professor of Energy Systems and the Environment and is a Giles Distinguished Professor and a Grisham Master Teacher at Mississippi State University. Since joining the faculty he has written two textbooks and developed six new courses as well as conducted research in a diverse range of thermal and fluid science topics. Dr. Hodge was the 1999-2000 President of the ASEE Southeastern Section.

J. D. Hardy: J. D. Hardy is a graduate student in the Department of Mechanical Engineering at Mississippi State University (MSU). In 2001, he received his BS degree in mechanical engineering from MSU and will obtain his MS in mechanical engineering in May 2003. His area of interest is the thermal sciences, especially energy systems.

Proceedings of the 2003 American Society for Engineering Education Annual Conference \& Exposition

Copyright C 2003, American Society for Engineering Education 